\title{
Ameliorative effects of green tea extract from tannase digests on house dust mite antigen-induced atopic dermatitis-like lesions in NC/Nga mice
}

\author{
YeonSil Hwang ${ }^{1} \cdot$ BoYoon Chang ${ }^{1} \cdot$ TaeYoung Kim² $^{2}$ SungYeon $\mathrm{Kim}^{1}$ (I)
}

Received: 5 March 2018 / Revised: 6 December 2018 / Accepted: 17 December 2018 / Published online: 7 January 2019

(c) The Author(s) 2019

\begin{abstract}
Atopic dermatitis (AD) is one of the most common chronic inflammatory skin diseases, which is affected by several factors. Anti-histamines, steroids, and immunosuppressive agents have been used for the treatment of AD. However, many studies have reported that long-term use and abuse of these drugs causes many side effects. This study was performed to evaluate the ameliorative effect of green tea extract on AD-like lesions in NC/Nga mice. Green tea extract from tannase digest (GTT), beta-hexosaminidase, and histamine were measured in IgE-antigen complex-stimulated RBL-2H3 cells. Dorsal skin application of house dust mite-ointment induced AD-like symptoms in NC/Nga mice. Dermatitis scores, skin moisture, transepidermal waterloss (TEWL), thickness of skin and ear, T-cell proliferation, levels of immunoglobulins and cytokines, and infiltration of mast cell were measured to assess the degree of AD induction. Skin moisture and TEWL were measured using probes, and ELISA was performed to measure the immunoglobulin and cytokine levels in blood. GTT was selected based on its ability to inhibit the release of beta-hexosaminidase and histamine in IgE-antigen complex-stimulated RBL-2H3 cells. Oral administration of GTT significantly suppressed the skin inflammation and symptoms of AD-like skin lesions in $\mathrm{NC} / \mathrm{Nga}$ mice. GTT may have a potential therapeutic effect in the treatment of AD.
\end{abstract}

Keywords Atopic dermatitis (AD) $\cdot$ Green tea extract $\cdot$ Tannase $\cdot$ House dust mite $\cdot$ NC/Nga

\section{Introduction}

The skin plays an important role in the body defense against harmful stimuli. Atopic dermatitis (AD) is a chronic inflammatory skin disease that causes severe itching and dry skin after contact with aeroallergens such as house dust mites, pollen, and animals [35]. Atopic dermatitis breaks down the barrier function of skin epidermis, causing external antigens to enter the skin and cause allergic reactions in the entire

YeonSil Hwang and BoYoon Chang contributed equally to this work.

SungYeon Kim

sungykim@wonkwang.ac.kr

1 Institute of Pharmaceutical Research and Development, College of Pharmacy, Wonkwang University, Iksan, Jeonbuk 54538, South Korea

2 \#703, Technology Development Center, BTC Corporation, 705 Haean-ro, Sangnok-gu, Ansan, Gyeonggi-do 15588, Republic of Korea body. It mainly affects young children, but $25 \%$ of the individuals with $\mathrm{AD}$ continue to suffer from it until adulthood [23]. Moreover, its prevalence has increased in urbanized societies over recent decades [39].

The treatment of $\mathrm{AD}$ involves the use of steroids, anti-histamines, and immunosuppressive agents [30]. Specifically, corticosteroids and calcineurin inhibitors are useful early stage treatments that can rapidly alleviate AD symptoms, but both show side effects such as steroid phobia, paradoxical skin disease, and skin irritation [10]. In addition, many studies have reported that long-term use or even abuse of these agents may result in various side effects, so recent studies have focused on complementary therapies based on alternative medicine. Several such studies have shown that natural products with anti-inflammatory properties have the potential to treat skin inflammatory disorders such as AD.

It was reported that $70 \%$ ethanol extract of Artemisia capillaris exerted inhibitory effects on AD-like skin lesions via the downregulation of serum histamine content and IgE expression [11]. Perilla leaf extract may inhibit the symptoms of $\mathrm{AD}$ via the suppression of macrophages by tumor 
necrosis factor- $\alpha$ (TNF- $\alpha)$. In this case, the main active ingredients are polyphenols, including rosmarinic acid, luteolin, and apigenin [33].

Green tea contains various active components, and it has been widely used as a herbal medicine. The bioactive compounds of green tea include polyphenols, polysaccharides, amino acids, and vitamins [8]. Catechins account for $75-80 \%$ of soluble ingredients in tea. The four types of tea catechins include epicatechin (EC), epigallocatechin (EGC), epicatechin gallate (EGC), and epigallocatechin gallate (EGCG). Tea catechins have received increased research interest because of their positive physiological and pharmacological effects combined with antimutagenic, anticarcinogenic, and antitumorigenic activities [3, 8]. High concentration enhances taste intensity, but also results in decreased taste palatability. Catechin bioavailability is very poor because of its large molecular size and the number of hydrogen bonds. Many enzymes have been used for tea processing and quality improvement for decades [3, 14]. Specifically, Tannase treatment is one of the best solutions to the drawbacks mentioned above. Tannase treatment of green tea extract is an efficient method for the biotransformation of catechins with enhanced radical-scavenging activity [4].

Recently, various studies suggested a beneficial effect of green tea on several dermatological disorders such as UVinduced inflammatory reaction [9]. In addition, bath therapy with green tea extracts is an effective treatment for AD [18]. However, it is not known whether oral administration of green tea extract or green tea extract from tannase digests can affect the AD-like symptoms in $\mathrm{NC} / \mathrm{Nga}$ mice.

Thus, the present study aimed to select an effective green tea extract from tannase digests using in vitro mast cell degranulation assay and evaluate its effect in reducing ADlike symptoms in house dust mite antigen-induced mouse model.

\section{Methods}

\section{Extraction a of green tea extract from tannase digests (GTT)}

The green tea extract from tannase digests (GTT) used in the experiments was provided by BTC. The following are the manufacturing process. For the extraction, $1 \mathrm{~kg}$ ground tea leaves (Osullocfarm, Gangjin, Korea) were added with $15 \mathrm{~L}$ water in a $50 \mathrm{~L}$ vessel (COSMOS660, Kyungseo E\&P., Korea), and then, it was extracted at $90{ }^{\circ} \mathrm{C}$ for $6 \mathrm{~h}$. After the extracts were filtered ( $5 \mu \mathrm{m}$ filter) to remove the insoluble components, $4 \mathrm{~g}$ tannase was added and the mixture was incubated at $40{ }^{\circ} \mathrm{C}$ for $2 \mathrm{~h}$ under $\mathrm{pH} 5.0-5.5$. Following this, to inactivate the enzymes, the enzymatic reaction was stopped by heating the mixture at $90{ }^{\circ} \mathrm{C}$ for $1 \mathrm{~h}$. The product was concentrated to 40 brix at $60{ }^{\circ} \mathrm{C}$ in a vacuum evaporator and dried in a freeze-dryer (FD8505, Ilshin Corp., Korea) to yield GTT $(47.5 \%, \mathrm{w} / \mathrm{w})$. The content of the marker galic acid, EGC, Caffeine, and EC in GTT was quantitated using high-performance liquid chromatography (HPLC).

\section{HPLC estimation of green tea extract from tannase digests (GTT)}

For HPLC analysis, green tea extract from tannase digests (GTT) was dissolved in HPLC-grade methanol to a concentration of $5 \mathrm{mg} / \mathrm{mL}$ and filtered through a $0.45 \mu \mathrm{m}$ syringe filter. The reference standard comprised $0.5 \mathrm{mg}$ gallic acid, caffeine, EGC, and EGCG in $1 \mathrm{~mL}$ HPLC-grade methanol. The HPLC system consisted of a model 515 pump and model 717 autosampler (Waters, Beverly, MA, USA). Reverse-phase separation was performed at room temperature using a Agilent Poroshell EC-C18 (I.D $4.6 \times 50$, $2.7 \mu \mathrm{m})$. The mobile phase included water containing $0.1 \%$ $\mathrm{H}_{3} \mathrm{PO}_{4}$ and acetonitrile. The flow rate was maintained at $1 \mathrm{~mL} / \mathrm{min}$ and the peak was detected at $280 \mathrm{~nm}$. The marker compound was identified by comparing the UV spectrum and retention time (Fig. 1).

\section{Anti-oxidant activities of green tea extracts}

To confirm the anti-oxidant activity of green tea extracts, 2,2-diphenyl-1-picrylhydrazyl (DPPH) radical-scavenging assay was performed using the method described by Klouwen [20]. The extracts were added with $0.2 \mathrm{mM}$ DPPH and incubated for $30 \mathrm{~min}$. Absorbance was measured at $520 \mathrm{~nm}$. The inhibition rate was calculated as follows: $(1-A / B) \times 100$, where $A$ is the absorbance of the sample and $B$ is the absorbance of the control. Vitamin $\mathrm{C}(50 \mu \mathrm{M})$ was used as a reference. Superoxide-radical-scavenging assay was also performed using the SOD assay kit-WST (Dojindo, Tokyo, Japan) according to the manufacturer's instructions. Optical density was measured at $450 \mathrm{~nm}$.

\section{Cell culture and cytotoxicity of green tea extracts on RBL-2H3 cells}

RBL-2H3 cells were obtained from Korea Cell Line Bank (Seoul, Korea) and cultured in RPMI with $10 \%$ FBS and $1 \%$ antibiotics at $37{ }^{\circ} \mathrm{C}$ in a humidified incubator under $5 \%$ $\mathrm{CO}_{2}$. Cells were plated at a density of $2 \times 10^{4}$ cells/well in a 96-well microplate and incubated for $24 \mathrm{~h}$. The cells were then cultured with green tea extracts at different concentrations $(10-100 \mu \mathrm{g} / \mathrm{mL})$. After $24 \mathrm{~h}$ incubation, the medium was changed, and $1 \mathrm{mg} / \mathrm{mL}$ methylthiazol tetrazolium (MTT, Sigma-Aldrich, St. Louis, MO, USA) was added, followed by the incubation of cells for another $2 \mathrm{~h}$ at $37^{\circ} \mathrm{C}$. The 


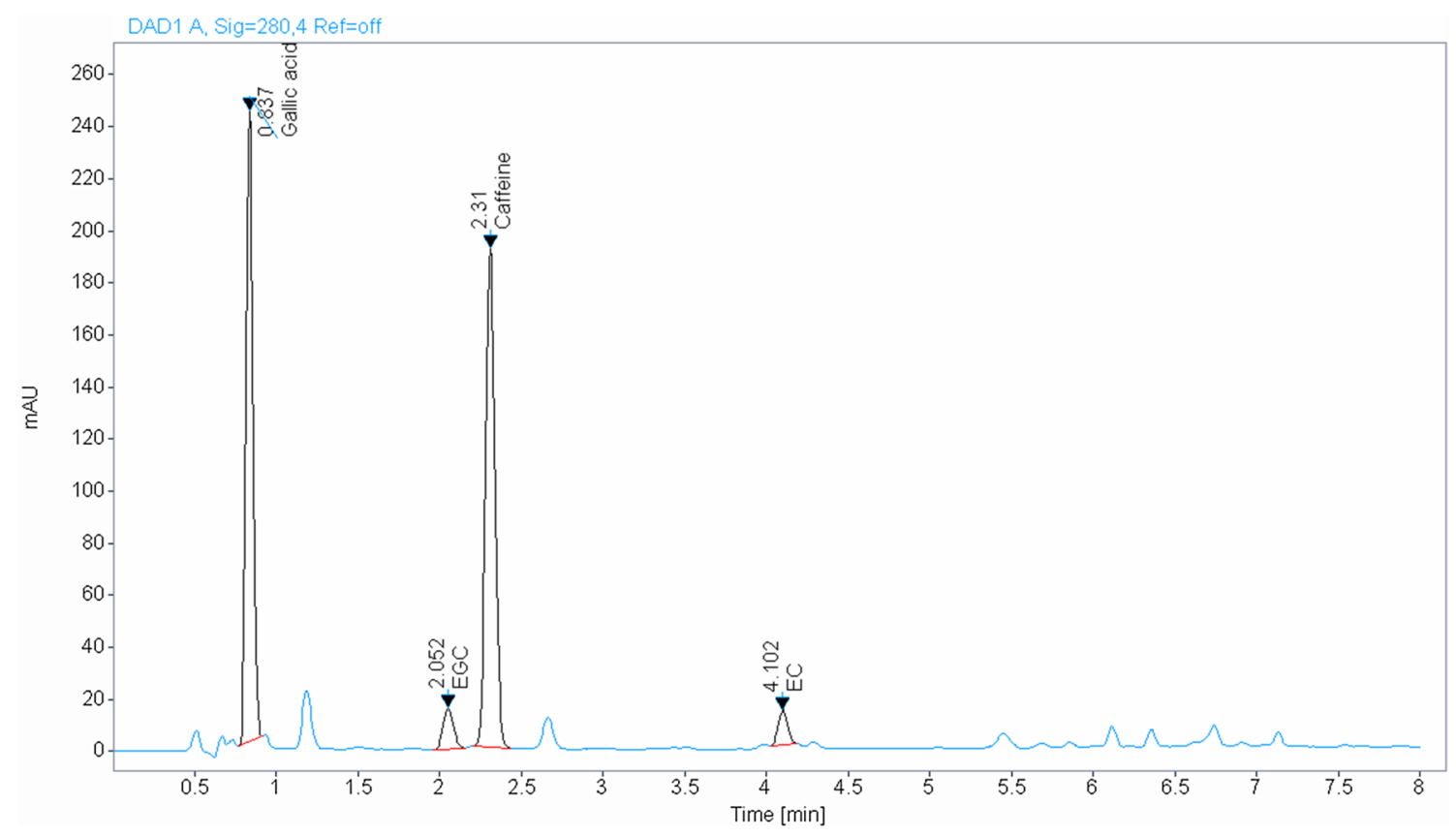

Fig. 1 HPLC analysis of green tea extract from tannase digest (GTT)

precipitate was dissolved in DMSO and the absorbance was measured at $540 \mathrm{~nm}$.

\section{Measurement of $\beta$-hexosaminidase and histamine contents on RBL-2H3 cells}

To measure the release of $\beta$-hexosaminidase and histamine on RBL-2H3 cells, cells were transferred onto a 24-well microplate $\left(2 \times 10^{5}\right.$ cells/well), and incubated with $0.5 \mu \mathrm{g} /$ $\mathrm{mL}$ anti-DNP-IgE overnight for cell sensitization. After washing with PIPES buffer ( $25 \mathrm{mM}$ PIPES, $119 \mathrm{mM} \mathrm{NaCl}$, $5 \mathrm{mM} \mathrm{KCl}, 5.6 \mathrm{mM}$ glucose, $0.4 \mathrm{mM} \mathrm{MgCl} 2,1 \mathrm{mM} \mathrm{CaCl}_{2}$,

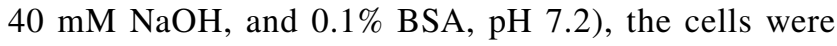
exposed to different concentrations of green tea extracts $(10-100 \mu \mathrm{g} / \mathrm{mL})$ or dexamethasone $(1 \mu \mathrm{M})$ in PIPES for $1 \mathrm{~h}$, and then stimulated with $50 \mu \mathrm{g} / \mathrm{mL}$ DNP-BSA for $24 \mathrm{~h}$. The cell-culture supernatant was used for the measurement of $\beta$-hexosaminidase and histamine contents.

For $\beta$-hexosaminidase assay, $25 \mu \mathrm{L}$ of cell-culture supernatant was incubated with $25 \mu \mathrm{L}$ of $5 \mathrm{mM}$ substrate solution (5 mM $p$-nitrophenyl- $N$-acetyl- $\beta$-D-glucosaminide dissolved in $0.2 \mathrm{M}$ sodium citrate buffer, $\mathrm{pH} 4.5$ ) at $37^{\circ} \mathrm{C}$ for $2 \mathrm{~h}$. The enzyme reaction was then terminated by adding $200 \mu \mathrm{L}$ of stop solution (0.1 $\left.\mathrm{M} \mathrm{Na}_{2} \mathrm{CO}_{3} / \mathrm{NaHCO}_{3}, \mathrm{pH} 10.0\right)$ and the absorbance was measured at $405 \mathrm{~nm}$ using a microplate reader.

To measure the amount of histamine, $22.5 \mu \mathrm{L}$ of $0.1 \mathrm{~N}$ $\mathrm{HCl}$ and $2.5 \mu \mathrm{L}$ of $60 \% \mathrm{HClO}_{4}$ were added to $25 \mu \mathrm{L}$ of cell-culture supernatant and the mixed samples were centrifuged at $1500 \mathrm{rpm}, 4{ }^{\circ} \mathrm{C}$ for $20 \mathrm{~min}$. The supernatant was transferred to tubes containing $25 \mu \mathrm{L}$ of $5 \mathrm{~N} \mathrm{NaOH}, 150 \mu \mathrm{L}$ of D.W, $500 \mu \mathrm{L}$ of $\mathrm{n}$-butanol, and $0.06 \mathrm{~g}$ of $\mathrm{NaCl}$. Then, the tubes were centrifuged at $2000 \mathrm{rpm}, 4^{\circ} \mathrm{C}$ for $10 \mathrm{~min}$. The upper organic phase was transferred to the new tubes, and added with $150 \mu \mathrm{L}$ of $0.1 \mathrm{~N} \mathrm{HCl}$ and $500 \mu \mathrm{L}$ of n-heptane, followed by centrifugation at $2000 \mathrm{rpm}, 4{ }^{\circ} \mathrm{C}$ for $10 \mathrm{~min}$. To $100 \mu \mathrm{L}$ of the lower aqueous phase, $200 \mu \mathrm{L}$ of $1 \mathrm{~N} \mathrm{NaOH}$ and $5 \mu \mathrm{L}$ of reaction solution (1\% o-phthaldialdehyde dissolved in methanol) were immediately added and mixed. After incubation at room temperature for $3 \mathrm{~min}$ (away from light), the reaction was terminated by the addition of $10 \mu \mathrm{L}$ of $3 \mathrm{~N} \mathrm{HCl}$. The fluorescence intensity was measured for excitation at $360 \mathrm{~nm}$ and emission at $450 \mathrm{~nm}$ using a fluorometer (SPECTRAMAX M2, Molecular Devices Co. Ltd. USA).

\section{Induction of atopic dermatitis (AD) and oral administration of green tea extract from tannase digests (GTT)}

Pathogen-free male NC/Nga mice, aged 6 weeks, with 22-25 g body weight, were purchased from the Central Lab Animal Incorporation (Seoul, Korea). The animals were housed at $23 \pm 3{ }^{\circ} \mathrm{C}$ under a $12 \mathrm{~h} \mathrm{light/dark} \mathrm{cycle} \mathrm{and} \mathrm{accli-}$ matized for 7 days in laboratory condition before the experiments. Food and water were provided ad libitum. All animal protocols were approved by the Committee of Wonkwang University (protocol number: WKU17-112).

At the start of the experiment, mice were randomly divided into the following six groups $(n=7$ for each 
group): normal, control, $3 \mathrm{mg} / \mathrm{kg}$ prednisolone, $100 \mathrm{mg} /$ $\mathrm{kg}$ GTT, $200 \mathrm{mg} / \mathrm{kg}$ GTT, and $400 \mathrm{mg} / \mathrm{kg}$ GTT. The experimental unit was a cage with a single animal. Atopic dermatitis-like skin lesions were induced by topical application of Biostir-AD (Biostir, Kobe, Japan), a hydrophilic petrolatum-based ointment containing extract of house dust mite. The hair on the upper dorsal skin of mice was shaved and $\mu \mathrm{L}$ of $4 \%(\mathrm{w} / \mathrm{v})$ sodium dodecyl sulfate was applied to the shaved skin for barrier disruption. After $30 \mathrm{~min}$, Biostir-AD was applied to the area twice a week. D.W, prednisolone, and GTT were orally administrated daily for 4 weeks. On day 28 , the mice were killed and the ear, dorsal skin, and blood were harvested for analysis. Any clinical signs related to toxicity, such as remarkable loss of body weight, were monitored in all groups of animals throughout the course of the experiment.

\section{Evaluation of dermatitis score and skin condition}

The severity of dermatitis was evaluated weekly, according to the degree of five symptoms: erythema, dry skin, edema/excoriation, erosion, and lichenification, which were scored individually as 0 (none), 1 (mild), 2 (moderate), or 3 (severe). The sum of individual scores was taken as the dermatitis score. The skin condition was confirmed by the measurement of skin moisture, transepidermal waterloss (TEWL), and ear thickness. The thickness of mice ear was measured using vernier calipers (Mitutoyo Corp., Japan) weekly. An MPA corneometer, CM825 (Epigen, Seoul, Korea), was used for the measurement of skin moisture, and a tewameter TM300 probe (Epigen, Seoul, Korea) was applied for measurement of transepidermal waterloss. Skin moisture and TEWL data were analyzed using the associated application software. Measurements were done weekly for all the test subjects on the upper dorsal skin, under the same temperature and humidity.

\section{Determination of splenocyte proliferation}

To determine ex-vivo cell proliferation, on day 28 , we harvested the spleen from the mice and isolated the primary splenocytes. These primary splenocytes were seeded in a 96-well microplate at $5 \times 10^{5}$ cells/well in complete RPMI. The cells were allowed to adhere for $4 \mathrm{~h}$ at $37{ }^{\circ} \mathrm{C}$ in a humidified $5 \% \mathrm{CO}_{2}$ atmosphere. After $4 \mathrm{~h}$ of incubation, the cells were stimulated with lipopolysaccharide (LPS, $10 \mu \mathrm{g} / \mathrm{mL}$ ) or concanavalin A (ConA, $5 \mu \mathrm{g} / \mathrm{mL}$ ). The stimulated cells were incubated for $21 \mathrm{~h}$, and then, cell viability was measured by MTT assay.

\section{Measurement of immunoglobulins, cytokines, and histamine levels by ELISA}

Blood samples were collected weekly and the total immunoglobulin E (IgE) levels were measured using an ELISA kit (Bethyl Laboratories, Inc., USA), according to the manufacturer's instructions. On day 28 , the whole blood was obtained and serum was separated by centrifugation. Amounts of IgG2a, histamine, IL-4, and IFN- $\gamma$ in the serum were measured using a Sandwich ELISA kit (Enzo Life Sciences Inc., Switzerland and BD Biosciences, USA) according to the manufacturer's instructions. Optical density was measured at $450 \mathrm{~nm}$.

\section{Histological analysis}

The dorsal skin lesions of mice were harvested and immediately fixed in $10 \%$ neutral buffered formalin and left for $2 \mathrm{~h}$. The fixed skin was then sliced and embedded in paraffin. Sections were cut from the blocks at $5 \mu \mathrm{m}$ thickness and stained with hematoxylin and eosin (H\&E) for the measurement of skin thickness. Toluidine blue stain was used to analyze the number of mast cells.

\section{Statistical analysis}

Data were expressed as mean \pm SD. Student's $t$ test was used to identify statistically significant differences, at a significance level of $p<0.05$.

\section{Results}

\section{Anti-oxidant activities of green tea extracts}

The anti-oxidant activities of green tea extracts were determined by measuring the free-radical-scavenging activities for DPPH and SOD. The DPPH free-radical-scavenging activity of green tea extracts increased with increase in the extract concentration. The DPPH radical-scavenging activity of green tea extracts at the concentration range of 10,30 , and $100 \mu \mathrm{g} / \mathrm{mL}$ was $63.2,89.0$, and $87.7 \%$. The positive control, $50 \mu \mathrm{M}$ of vitamin $\mathrm{C}$, showed the greatest scavenging ability of $72.1 \%$. The scavenging activities of green tea extracts at 30 and $100 \mu \mathrm{g} / \mathrm{mL}$ were significantly higher than the scavenging activity of vitamin C. GTT used in the present investigation was also tested for their superoxide-radicalscavenging activity. The ability to scavenge superoxide radicals ranged from 42.0 to $85.4 \%$. The value increased with an increase in the extract concentrations. The positive control, $500 \mu \mathrm{g} / \mathrm{mL}$ of trolox, had a superoxide-radical-scavenging ability as $58.1 \%$. GTT at concentrations greater than $30 \mu \mathrm{g} /$ $\mathrm{mL}$ was more effective than the positive control. In terms of 
DPPH and superoxide-radical-scavenging activity, all green tea extracts showed similar anti-oxidative effect (Fig. 2).

\section{Cytotoxicity of green tea extracts on RBL-2H3 cells}

To evaluate the cytotoxicity of green tea extracts on RBL$2 \mathrm{H} 3$ cells, the cells were treated with different concentrations of green tea extracts for $24 \mathrm{~h}$, and the MTT [3-(4,5-dimethylthiazol-2-yl)-2,5-diphenyl-tetrazolium bromide] method was used for the cytotoxicity assay. As shown in Fig. 3a, green tea extracts had no significant cytotoxicity on RBL$2 \mathrm{H} 3$ cells.

\section{Effect of green tea extracts on the release of $\beta$-hexosaminidase and histamine in IgE-antigen complex-stimulated RBL-2H3 cells}

The inhibitory effect of green tea extracts on IgE-mediated degranulation in RBL-2H3 cells was measured using $\beta$-hexosaminidase and histamine secretions as degranulation biomarkers. The release of $\beta$-hexosaminidase and histamine in IgE-antigen complex-stimulated RBL-2H3 cells was significantly increased compared with control cells. Pretreatment with $1 \mu \mathrm{M}$ of dexamethasone, the positive control, significantly suppressed the degranulation in IgE-antigen complex-stimulated RBL-2H3 cells. The GTT effectively reduced the release of $\beta$-hexosaminidase and histamine at all concentrations in RBL-2H3 cells stimulated with IgEantigen complex (Fig. 3b, c). Therefore, GTT was chosen for use in AD-like animal model.

\section{Effect of orally administered GTT on atopic dermatitis (AD) symptoms in NC/Nga mice}

To evaluate the therapeutic effect of GTT on AD, AD was induced in mice by topical application of house dust mite (HDM) antigen for 28 days. After 14 days, dermatitis scores increased due to the induced $\mathrm{AD}$, and oral administration of GTT resulted in a dose-dependent reduction in the dermatitis scores. The positive control ( $5 \mathrm{mg} / \mathrm{kg}$ of prednisolone) as well as $400 \mathrm{mg} / \mathrm{kg}$ of GTT significantly decreased the dermatitis scores during the experimental period.

When AD gets worse, the skin moisture was decreased. We analyzed the skin moisture content and transepidermal
Fig. 2 DPPH and SOD radicalscavenging activities of green tea extracts for screening. a DPPH radical-scavenging activity increased significantly compared with the control in a dose-dependent manner. b Superoxide-radical-scavenging activity was significantly increased compared with the control in a dose-dependent manner. Experiments were performed three times. Data are shown as mean $\pm \mathrm{SD}$ of the changes in DPPH and superoxide-radical-scavenging activity. $* * * p<0.001$ compared with the control
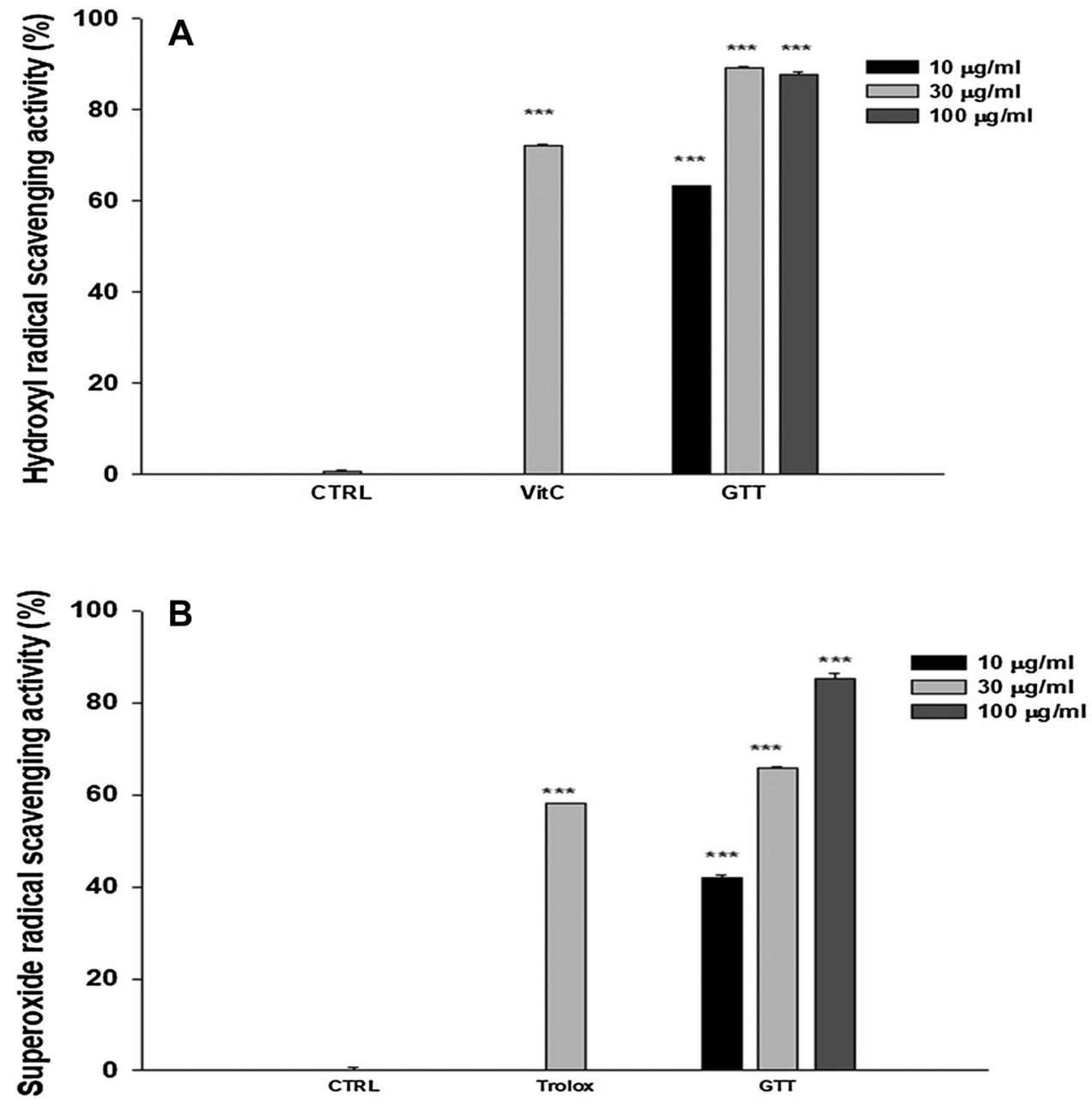

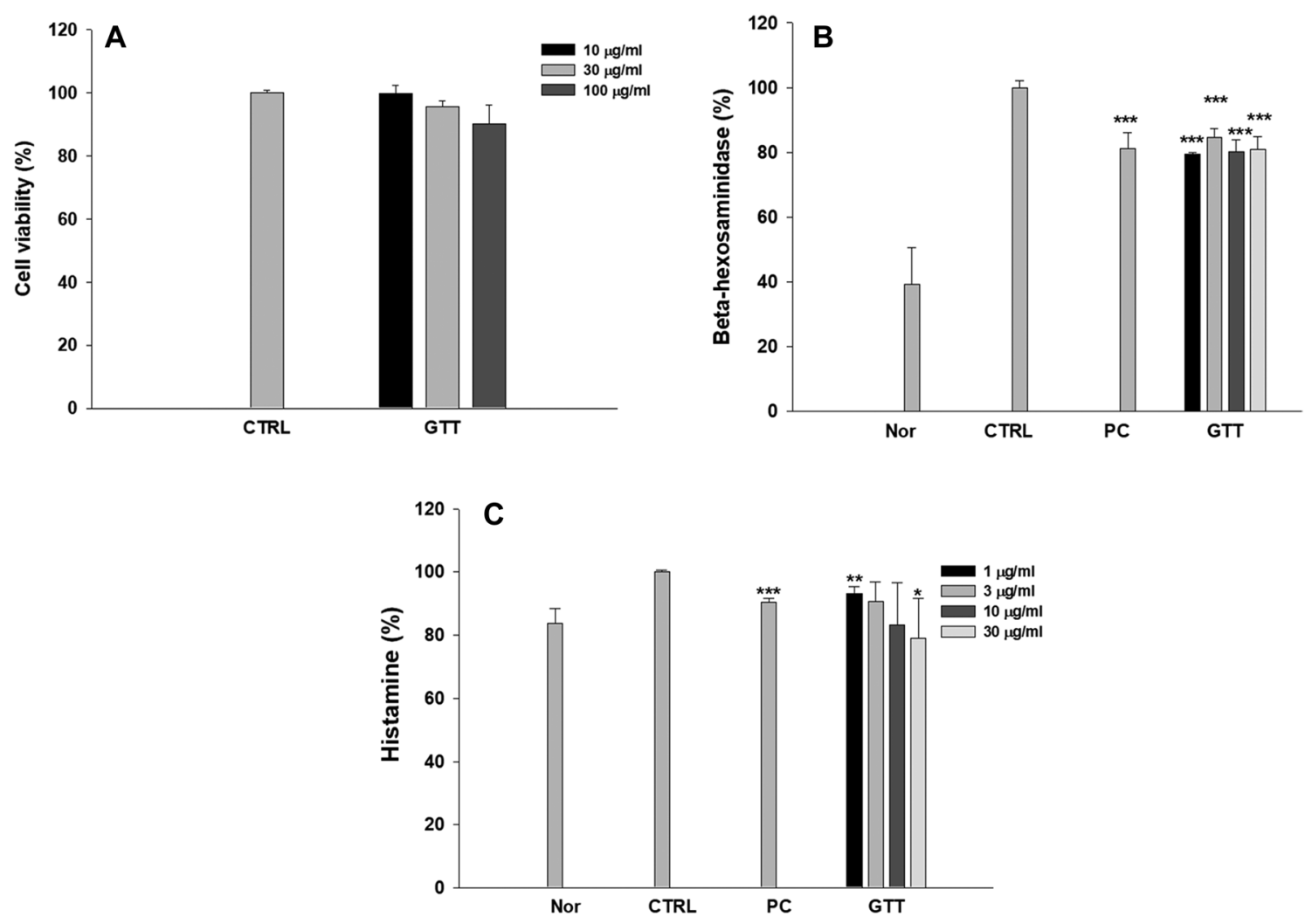

Fig. 3 Cytotoxicity of green tea extracts and inhibitory effects on the release of $\beta$-hexosaminidase and histamine by green tea extracts on RBL-2H3 cells for screening. a Cell viability of green tea extracts on RBL-2H3 cells. Green tea extracts had no significant cytotoxicity on RBL-2H3 cells. b Inhibitory effects of green tea extracts on $\beta$-hexosaminidase from IgE-antigen complex-stimulated RBL-2H3 cells. Sample no. 7, the green tea GTT, had a significant inhibitory effect at all concentrations. Therefore, GTT was selected for measuring histamine release. $\mathbf{c}$ Inhibitory effect of GTT on histamine release from IgE-antigen complex-stimulated RBL-2H3 cells. The levels of $\beta$-hexosaminidase and histamine were significantly decreased by GTT administration in a dose-dependent manner. Experiments were performed three times. Data are shown as mean \pm SD. ${ }^{*} p<0.05$, $* * p<0.01$, and $* * * p<0.001$ compared with control waterloss (TEWL). On day 14, the moisture capacity of the dorsal skin of mice was decreased by the induced $\mathrm{AD}$ and prednisolone, and high concentrations of GTT resulted in a significant recovery of the skin moisture. After 21 days, the hair of the dorsal skin interrupted the measurement of skin moisture, so the skin moisture measurements could not be carried out. However, TEWL was measured throughout these experiments, which increased with HDM and decreased by oral administration of prednisolone and GTT. GTT significantly decreased the TEWL in a dose-dependent manner.

As shown in Fig. 4c, the ear thickness became thicker in the AD-induced group. However, oral administration of prednisolone significantly alleviated the thickening of the ears. In addition, GTT significantly alleviated the thickening of the ears in a dose-dependent manner.

\section{Inhibitory effect of GTT on the proliferation of splenocytes}

On day 28, we killed the AD-induced mice and the weight of their spleen was measured. Spleen of the AD-induced mice was bigger compared with the control. However, prednisolone and $400 \mathrm{mg} / \mathrm{kg}$ GTT treatments resulted in recovered normal weight of the spleen. The inhibitory effect on the proliferation of splenocytes by GTT was determined by MTT assay. LPS stimulates B-cell proliferation and ConA stimulates T-cell proliferation. Both prednisolone and GTT did not affect the LPS-induced splenocyte proliferation, but ConA-induced splenocyte was significantly enhanced by the induced $\mathrm{AD}$ and significantly decreased by the administration in a dose-dependent manner. These results suggested that the $\mathrm{AD}$ might be related to stimulation of $\mathrm{T}$ cells and 
A
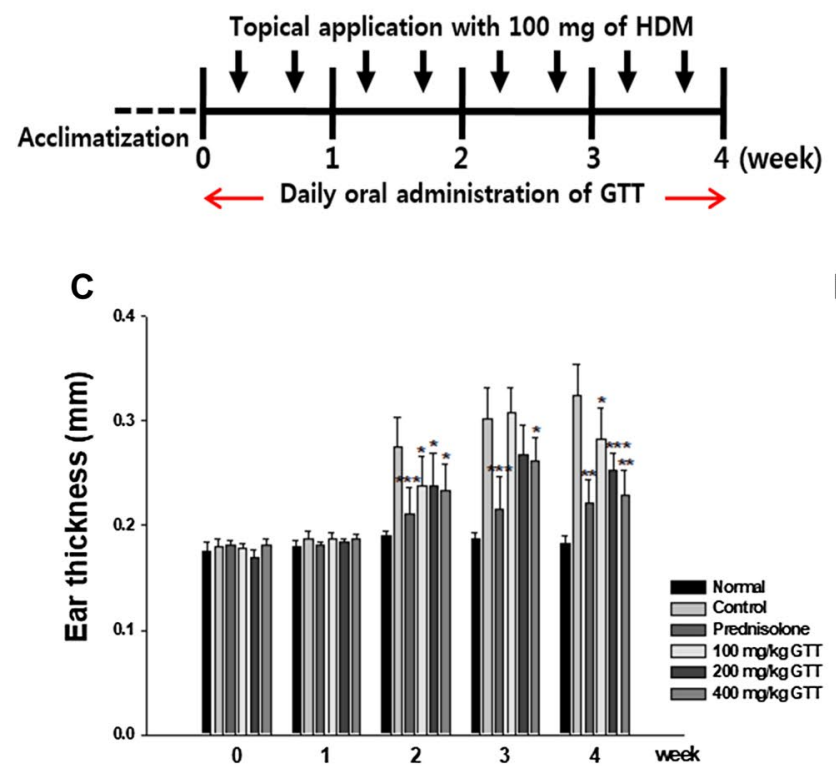

B

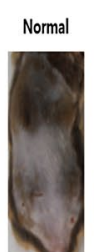

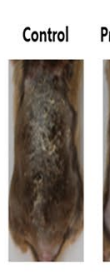
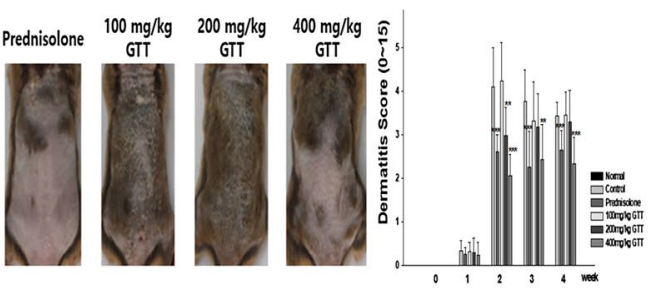

D
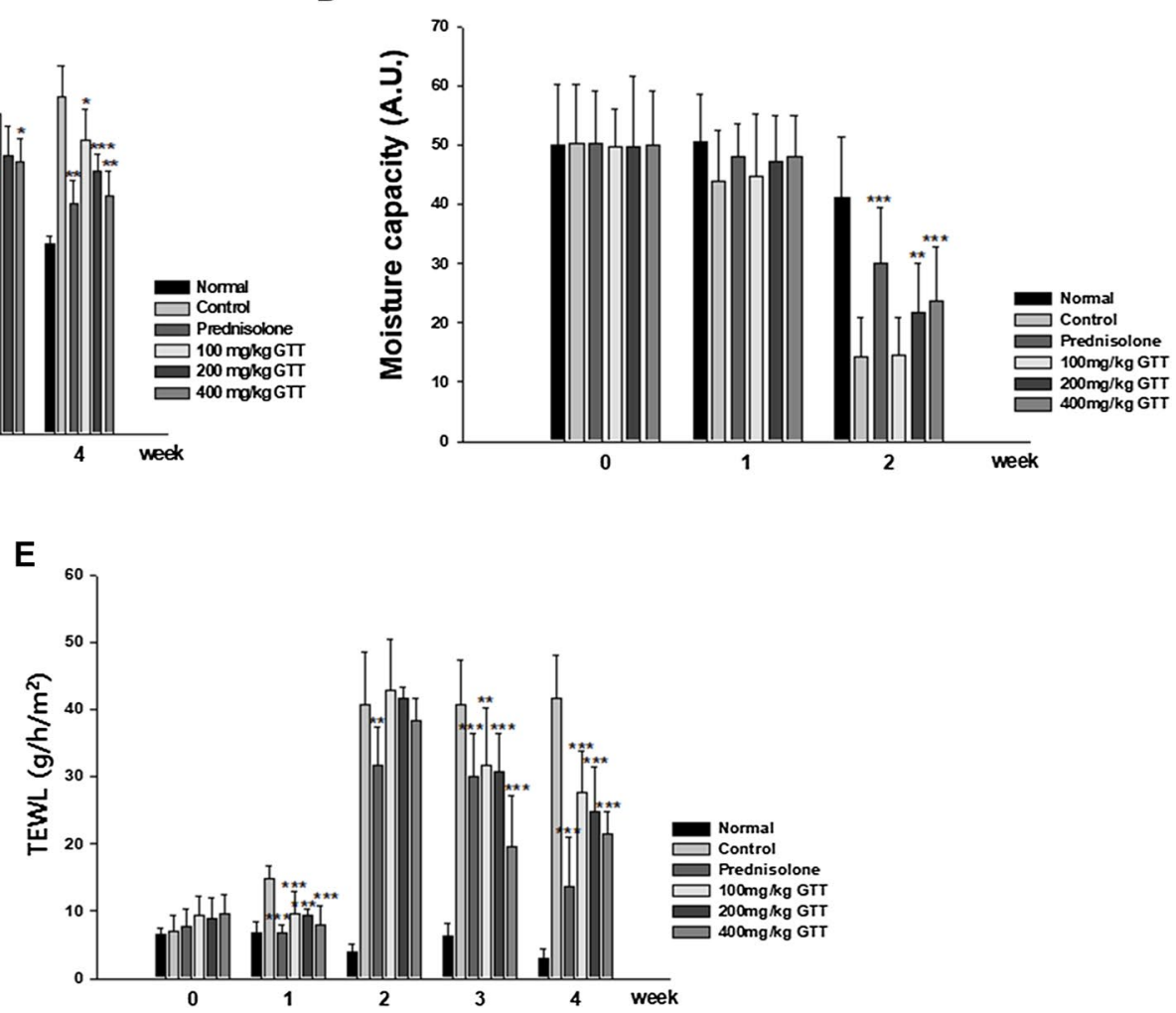

Fig. 4 Experimental procedure and changes in the severity of atopic dermatitis-like skin conditions a For the induction of AD-like symptoms, house dust mite (HDM) was topically applied to the skin of $\mathrm{NC} / \mathrm{Nga}$ mice twice weekly for 4 weeks. Mice were fed daily with GTT for 4 weeks. b Weekly dermatitis scores were evaluated during the treatment period. c Ear thickness was measured with a vernier caliper. d Moisture capacity of the skin was measured weekly with a

GTT could alleviate the AD by inhibiting the stimulation of T cells (Fig. 5).

\section{Effect of GTT on the production of immunoglobulins, cytokines, and histamine}

To determine whether orally administered GTT affects the production of immunoglobulins, cytokines, and histamine, blood was collected from the mice. Application of HDM antigen resulted in a high concentration of IgE in NC/Nga mice. Compared with the control group, IgE concentration was significantly downregulated in prednisolone and $400 \mathrm{mg} / \mathrm{kg}$ GTT-fed groups. Otherwise, IgG2a was decreased by the induced AD
CM825 probe for 2 weeks. e Transepidermal waterloss (TEWL) is the evaporation of skin moisture. It was weekly measured with a TM300 probe for 4 weeks. GTT resulted in a significant recovery from atopic dermatitis-like skin condition. Sample size was $n=7$ per group. Data are shown as mean \pm SD. $* p<0.05, * * p<0.01$, and $* * * p<0.001$ compared with the control

and significantly increased by the administration of prednisolone and $400 \mathrm{mg} / \mathrm{kg}$ GTT. The amounts of Th1 cytokine IFN- $\gamma$ and Th 2 cytokine IL- 4 in the blood did not differ significantly by the induction of AD. The histamine level of blood was significantly increased by the induced $\mathrm{AD}$ and decreased by the administration of $400 \mathrm{mg} / \mathrm{kg}$ GTT, but there was no inhibitory effect of the positive control, prednisolone (Fig. 6).

\section{GTT administration decreased skin thickness and local infiltration of mast cells}

Figure 7 shows the changes in the histopathological features of the lesions on dorsal skin of NC/Nga mice. The 
Fig. 5 Changes in splenocyte numbers and splenomegaly in atopic dermatitis-like lesions. a Spleen weight was measured on day 28. B Proliferation of splenocytes obtained from $\mathrm{NC} / \mathrm{Nga}$ mice was measured by MTT assay on day 28. LPS stimulates B-cell proliferation and ConA stimulates T-cell proliferation. ConA-induced splenocytes were significantly enhanced by the induction of AD. Splenomegaly and the proliferation of $\mathrm{T}$ cells were significantly decreased by GTT in a dose-dependent manner. Sample size was $n=7$ per group. Data are shown as mean \pm SD. $* p<0.05$ and $* * * p<0.001$ compared with control
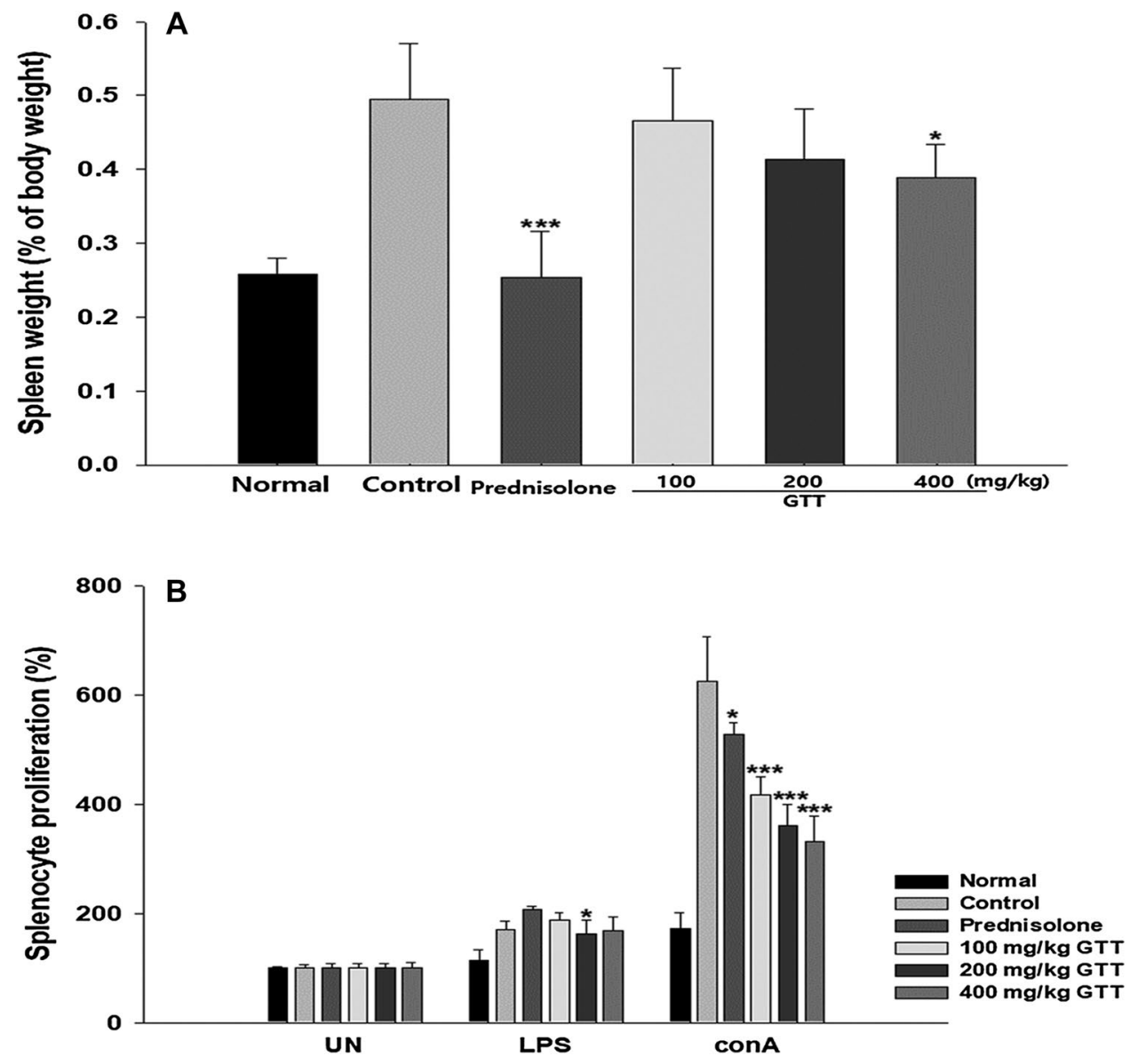

control mice had increased infiltration of inflammatory cells and highly thickened epidermis, with a mean value of $41.9 \pm 11.2 \mu \mathrm{m}$ compared with $12.5 \pm 4.3 \mu \mathrm{m}$ in control mice. The thickness of the epidermis was measured to evaluate the progress of lichenification. Lichenification is a symptom of chronic AD. Prednisolone-fed mice showed recovery in the increased thickness of the skin, showing values similar to the mice without dermatitis. In comparison with the control group, all groups that received GTT showed less hyperplasia in the epidermis and less infiltration of inflammatory cells. Doses of 100,200 , and $400 \mathrm{mg} / \mathrm{kg}$ GTT resulted in epidermal thicknesses of $25.5 \pm 8.6,28.4 \pm 8.9$, and $22.8 \pm 9.5 \mu \mathrm{m}$, respectively. Infiltrated mast cells in the skin lesions were stained with toluidine blue and counted (Fig. 7b). In contrast to the large numbers of mast cells in the control mice, GTTfed mice showed significantly fewer mast cells.

\section{Discussion}

Many researchers are constantly studying extraction techniques to improve the functionality and taste of tea $[8,13$, 24]. Among them, the role of enzymes in the processing and their application to improve the quality of tea has been recognized. Tea leaves are treated enzymatically with common cell-wall digesting enzymes such as pectinase, cellulose, amylases, and proteases prior to extraction to improve the extract yield and also with tannase to improve cold-water extract ability. Tannase have been characterized mostly by their activity with respect to complex poly phenolics and hydrolyze the ester bond and the depside bond of substrates such as tannic acid, EGCG, ECG, and chlorogenic acid [4]. According to Hong et al., tannase improves the extraction efficiency of polyphenols and increases radical-scavenging activities. In this study, several experiments were performed to evaluate the efficacy of green tea extract in tannase digest (GTT) to in alleviating AD-like immune alteration [14].

In general, $\mathrm{AD}$ is an immunological disease resulting from an imbalance favoring type- 2 helper $\mathrm{T}$ (Th2) cell. Th2 cells, mast cells, or other immune components cells produce interleukin-4 (IL-4), which is known to induce B-cell class switching to $\operatorname{IgE}[7,26,29]$. Up-regulation of $\operatorname{IgE}$ production is a hallmark of AD in humans [15]. Th1 cells, natural killer cells, and other immune cells produce IFN- $\gamma$ that triggers the isotype-switching to IgG2a in mice [31, 32]. Therefore, analysis of the $\operatorname{IgE}$ and $\operatorname{IgG} 2 \mathrm{a}$ levels could reflect the alteration of homeostasis between type- 1 and type- 2 immune responses. 

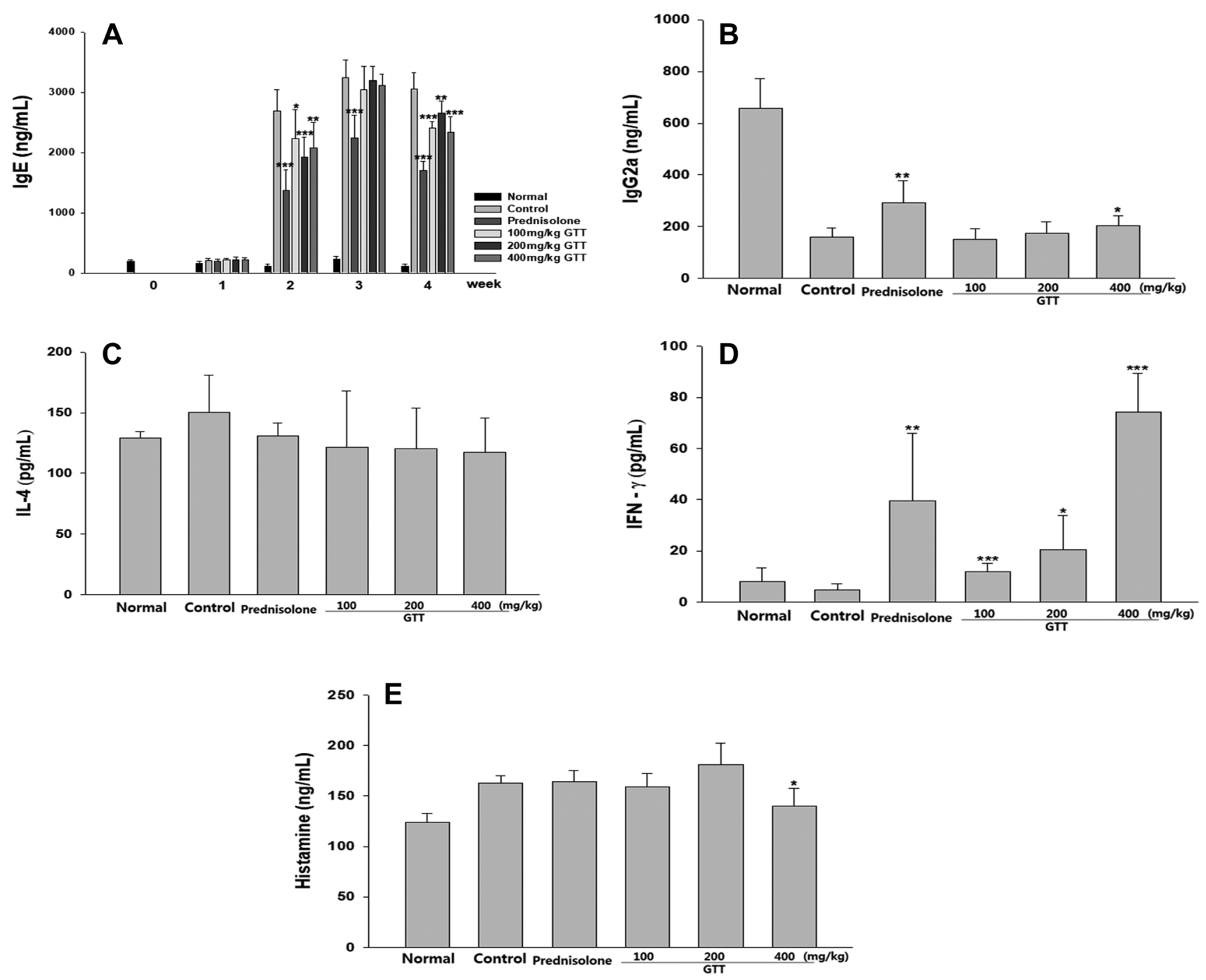

Fig. 6 Effect of consecutive administration of GTT on the concentrations of immunoglobulins, cytokines, and histamine in atopic dermatitis-like lesions. a Blood samples were collected weekly during the experimental period. On day $28,400 \mathrm{mg} / \mathrm{kg}$ GTT significantly reduced the increased IgE levels in blood. b Level of IgG2a was measured using ELISA on day 28. The decreased IgG2a level was

Likewise, mast cells are the primary effector cells involved in the allergic inflammatory reaction. The degranulation process starts by the interaction of antigens with mast cells [37]. In addition, mast cells secrete a variety of bioactive substances such as histamine and pro-inflammatory cytokines $[22,25]$. Histamine is a hallmark of allergic responses and induces vascular permeability [2]. Since histamine is immediately released following exposure to allergen, an increased histamine level is often considered a parameter to diagnose the onset of allergic diseases [16]. This study initially screened several green tea extracts based on their antioxidant ability and the inhibitory effect due to the release of $\beta$-hexosaminidase on IgE-antigen complex-stimulated increased by the administration of GTT. c-e The levels of cytokines and histamine in the blood were not significantly changed by the induction of atopic dermatitis. Sample size was $n=7$ per group. Data are shown as mean $\pm \mathrm{SD}$. $* p<0.05, * * p<0.01$, and $* * * p<0.001$ compared with control

RBL-2H3 cells. The selected green tea extract also inhibited the release of histamine in the same cells. RBL-2H3 is a basophilic leukemia cell line and has characteristics of mucosal-type mast cells [6]. This cell line is considered to be a good model for studying comprehensive events on mast cell activation [28]. GTT significantly suppressed the release of $\beta$-hexosaminidase and histamine without cytotoxic effect on mast cells. As a result, we selected GTT as the therapeutic ingredient for $\mathrm{AD}$.

The NC/Nga mouse has a mutation on chromosome 9, which is related to the increased production of $\mathrm{IgE}$ and a Th2-dominant inflammation [1]. However, exposure to a standard environment alone is not enough to reveal AD-like 
A
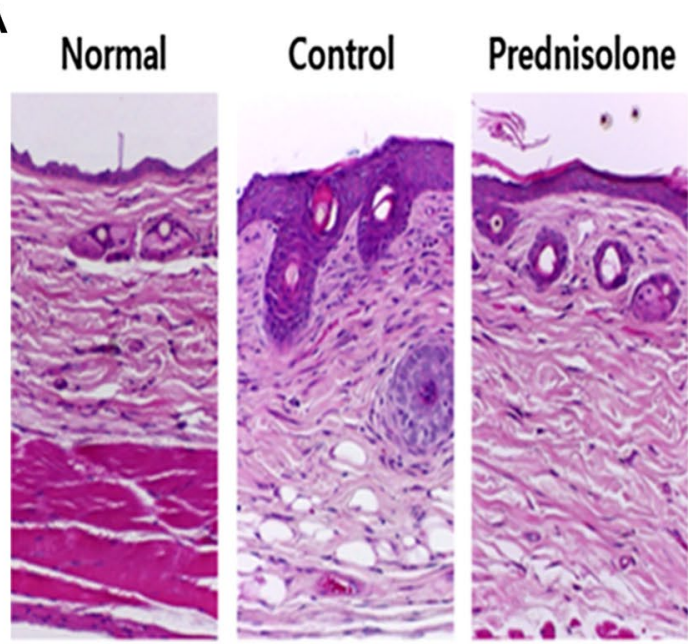

B
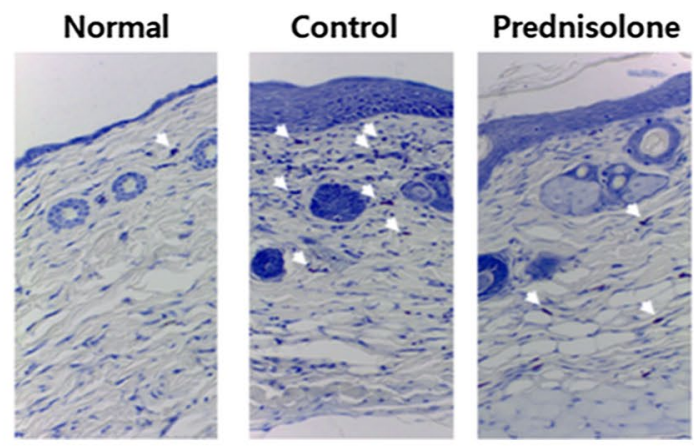

C

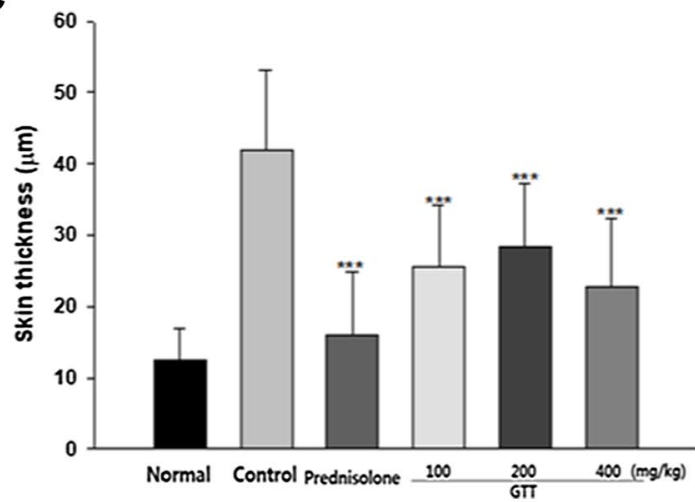

Fig. 7 Effect of GTT on skin thickness and local infiltration of mast cells. a, c Hematoxylin and eosin stained the dorsal skin sections of NC/Nga mice $(\times 200)$. Atopic dermatitis and administration of GTT significantly changed the epidermal thickness. b, $\mathbf{d}$ Toluidine blue-

symptoms in these mice. Continuous skin irritation with certain environmental allergens (e.g., house dust mite allergens) in NC/Nga mice could provoke AD-like symptoms [19]. In this study, AD was induced twice a week for 28 days and GTT was orally administered daily at the same periods. The dermatitis scores were evaluated by observing erythema, dry
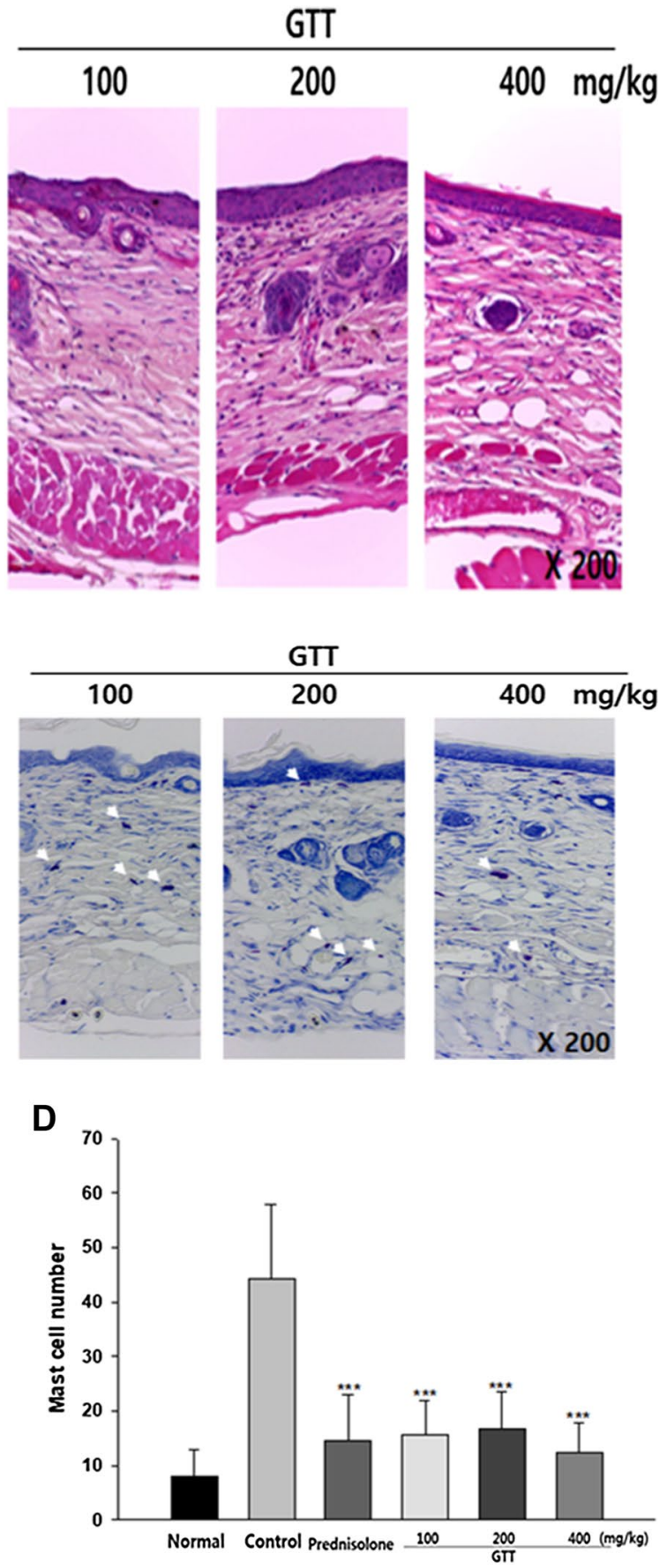

stained violet mast cells in the skin sections $(\times 200)$. GTT inhibited the infiltration of mast cells into the skin. Sample size was $n=7$ per group. Data are shown as mean $\pm \mathrm{SD}$. $* * * p<0.001$ compared with the control

skin, edema/excoriation, erosion, and lichenification [36]. The skin thickness was used as an indicator of lichenification, frequently observed in chronic AD [38]. The ears thickened by AD were thinned by GTT. Administration of GTT increased the moisture capacity of the skin and reduced the moisture evaporation of the skin, thereby alleviating the 
dryness of the skin. These results showed that the administration of GTT effectively regulates various clinical symptoms associated with AD.

Atopic dermatitis is an inappropriate immune response, involving an excessive Th2 response [5]. This study showed that the proliferation of T-cell stimulation by con A was increased by the induced AD and decreased by the administration of GTT. The type-2 response becomes predominant when the differentiation or activation of Th2 cells is preferred, but development or stimulation of Th1 cells is suppressed [12, 27]. Orally administered GTT decreased the IgE and increased the IgG2a in the blood of NC/Nga mice. It suggests a possibility that GTT is able to modulate the immune activation of mast cells, because these cells have the surface receptor for IgE to induce their activation and secretion of inflammatory mediators [34]. The epidermal thickness in GTT-administered mice was thinned compared with the mice in the control group. The infiltration of various immune cells, including mast cells, into the skin lesions is a characteristic feature of $\mathrm{AD}$ [17]. Mast cells play a central role in $\mathrm{AD}$ through degranulation of inflammatory mediators by binding IgE onto the cells [21]. Decreased infiltration of mast cells by GTT administration is expected to play a role in the reduction of skin inflammation.

In conclusion, orally administered green tea extract from tannase digest (GTT) suppressed the inflammation of ADlike skin lesions, and decreased the immune cell infiltration into the skin. These results suggest that GTT may have a therapeutic potential in the treatment of AD.

Acknowledgements This study was supported by the Ministry of Trade, Industry \& Energy (MOTIE), Korea Institute for Advancement of Technology (KIAT), through the Encouragement Program for The Industries of Economic Cooperation Region (R004933).

\section{Compliance with ethical standards}

Conflict of interest The authors have no conflict of interest to declare.

Ethical approval All procedures performed in studies involving animals were in accordance with the ethical standards of the Committee of Wonkwang University at which the studies were conducted. The university animal care committee for animal research of the Wonkwang University approved the study protocol (protocol number: WKU17112).

Informed consent Informed consent was obtained from all individual participants included in the study.

OpenAccess This article is distributed under the terms of the Creative Commons Attribution 4.0 International License (http://creativeco mmons.org/licenses/by/4.0/), which permits unrestricted use, distribution, and reproduction in any medium, provided you give appropriate credit to the original author(s) and the source, provide a link to the Creative Commons license, and indicate if changes were made.

\section{References}

1. Aioi A, Tonogaito H, Suto H, Hamada K, Ra CR, Ogawa H, Maibach H, Matsuda H (2001) Impairment of skin barrier function in $\mathrm{NC} / \mathrm{Nga}$ Tnd mice as a possible model for atopic dermatitis. Br J Dermatol 144(1):12-18

2. Ashina K, Tsubosaka Y, Nakamura T, Omori K, Kobayashi K, Hori M, Ozaki H, Murata T (2015) Histamine induces vascular hyperpermeability by increasing blood flow and endothelial barrier disruption in vivo. PLoS One 10(7):e0132367

3. Baik JH, Shin KS, Park Y, Yu KW, Suh HJ, Choi HS (2015) Biotransformation of catechin and extraction of active polysaccharide from green tea leaves via simultaneous treatment with tannase and pectinase. J Sci Food Agric 95(11):2337-2344

4. Baik JH, Suh HJ, Cho SY, Park Y, Choi HS (2014) Differential activities of fungi-derived tannases on biotransformation and substrate inhibition in green tea extract. J Biosci Bioeng 118(5):546-553

5. Bajgai J, Fadriquela A, Ara J, Begum R, Ahmed MF, Kim CS, Kim SK, Shim KY, Lee KJ (2017) Balneotherapeutic effects of high mineral spring water on the atopic dermatitis-like inflammation in hairless mice via immunomodulation and redox balance. BMC Complement Altern Med 17(1):481

6. Barsumian EL, Isersky C, Petrino MG, Siraganian RP (1981) IgEinduced histamine release from rat basophilic leukemia cell lines: isolation of releasing and nonreleasing clones. Eur J Immunol 11(4):317-323

7. Choi YA, Choi JK, Jang YH, Lee S, Lee SR, Choi JH, Park JH, Shin TY, Kim SH (2017) Antiinflammatory effect of Amomum xanthioides in a mouse atopic dermatitis model. Mol Med Rep 16(6):8964-8972

8. Crespy V, Williamson G (2004) A review of the health effects of green tea catechins in in vivo animal models. J Nutr 134:3431s-3440s

9. Farrar MD, Nicolaou A (2015) A randomized controlled trial of green tea catechins in protection against ultraviolet radiationinduced cutaneous inflammation. Am J Clin Nutr 102(3):608-615

10. Guttman-Yassky E, Nograles KE, Krueger JG (2011) Contrasting pathogenesis of atopic dermatitis and psoriasis-part I: clinical and pathologic concepts. J Allergy Clin Immunol 127(5):1110-1118

11. Ha H, Lee H, Seo CS, Lim HS, Lee JK, Lee MY, Shin H (2014) Artemisia capillaris inhibits atopic dermatitis-like skin lesions in Dermatophagoides farinae-sensitized Nc/Nga mice. BMC Complement Altern Med 14:100

12. Heo Y (2005) In vitro model for modulation of helper T cell differentiation and activation. Curr Protoc Toxicol Chapter 18:Unit18.9

13. Hong YH, Jung EY, Park Y, Shin KS, Kim TY, Yu KW, Chang UJ, Suh HJ (2013) Enzymatic improvement in the polyphenol extractability and antioxidant activity of green tea extracts. Biosci Biotechnol Biochem 77(1):22-29

14. Hong YH, Jung EY, Shin KS, Yu KW, Chang UJ, Suh HJ (2013) Tannase-converted green tea catechins and their anti-wrinkle activity in humans. J Cosmet Dermatol 12(2):137-143

15. Ilves M, Palomaki J, Vippola M, Lehto M, Savolainen K, Savinko $\mathrm{T}$, Alenius $\mathrm{H}$ (2014) Topically applied $\mathrm{ZnO}$ nanoparticles suppress allergen induced skin inflammation but induce vigorous IgE production in the atopic dermatitis mouse model. Part Fibre Toxicol $11: 38$

16. Jensen BM, Falkencrone S, Skov PS (2014) Measuring histamine and cytokine release from basophils and mast cells. Methods Mol Biol 1192:135-145

17. Jeong YI, Hong SH, Cho SH, Lee WJ, Lee SE (2015) Toxoplasma gondii infection suppresses house dust mite extract-induced 
atopic dermatitis in NC/Nga Mice. Allergy Asthma Immunol Res 7(6):557-564

18. Kim HK, Chang HK, Baek SY, Chung JO, Rha CS, Kim SY, Kim BJ, Kim MN (2012) Treatment of atopic dermatitis associated with Malassezia sympodialis by green tea extracts bath therapy: a pilot study. Mycobiology 40(2):124-128

19. Kim JY, Jeong MS, Park MK, Lee MK, Seo SJ (2014) Timedependent progression from the acute to chronic phases in atopic dermatitis induced by epicutaneous allergen stimulation in $\mathrm{NC} /$ Nga mice. Exp Dermatol 23(1):53-57

20. Klouwen HM (1962) Determination of the sulfhydryl content of thymus and liver using DPPH. Arch Biochem Biophys 99:116-120

21. Lee SH, Yoon JM, Kim YH, Jeong DG, Park S, Kang DJ (2016) Therapeutic effect of tyndallized Lactobacillus rhamnosus IDCC 3201 on atopic dermatitis mediated by down-regulation of immunoglobulin E in NC/Nga mice. Microbiol Immunol 60(7):468-476

22. Lian Q, Cheng Y, Zhong C, Wang F (2015) Inhibition of the IgEmediated activation of RBL-2H3 cells by TIPP, a novel thymic immunosuppressive pentapeptide. Int J Mol Sci 16(1):2252-2268

23. Lyons JJ, Milner JD, Stone KD (2015) Atopic dermatitis in children: clinical features, pathophysiology, and treatment. Immunol Allergy Clin N Am 35(1):161-183

24. Molto J, Valle M, Miranda C, Cedeno S, Negredo E, Barbanoj MJ, Clotet B (2011) Herb-drug interaction between Echinacea purpurea and darunavir-ritonavir in HIV-infected patients. Antimicrob Agents Chemother 55(1):326-330

25. Morimoto K, Shirata N, Taketomi Y, Tsuchiya S, Segi-Nishida E, Inazumi T, Kabashima K, Tanaka S, Murakami M, Narumiya S, Sugimoto Y (2014) Prostaglandin E2-EP3 signaling induces inflammatory swelling by mast cell activation. J Immunol 192(3):1130-1137

26. Park KI, Kim DG, Yoo JM, Ma JY (2016) The herbal medicine KIOM-MA128 inhibits the antigen/IgE-mediated allergic response in vitro and in vivo. Molecules 21(8):E1015

27. Park S, Kim DS, Kang S, Shin BK (2015) Synergistic topical application of salt-processed Phellodendron amurense and Sanguisorba officinalis Linne alleviates atopic dermatitis symptoms by reducing levels of immunoglobulin $\mathrm{E}$ and pro-inflammatory cytokines in NC/Nga mice. Mol Med Rep 12(5):7657-7664
28. Passante E, Frankish N (2009) The RBL-2H3 cell line: its provenance and suitability as a model for the mast cell. Inflamm Res 58(11):737-745

29. Pucheu-Haston CM, Bizikova P, Marsella R, Santoro D, Nuttall T, Eisenschenk MN (2015) Review: lymphocytes, cytokines, chemokines and the T-helper 1-T-helper 2 balance in canine atopic dermatitis. Vet Dermatol 26(2):124-132

30. Saeki H, Furue M, Furukawa F, Hide M, Ohtsuki M, Katayama I, Sasaki R, Suto H, Takehara K (2009) Guidelines for management of atopic dermatitis. J Dermatol 36(10):563-577

31. Sung YY, Lee AY, Kim HK (2016) Forsythia suspensa fruit extracts and the constituent matairesinol confer anti-allergic effects in an allergic dermatitis mouse model. J Ethnopharmacol 187:49-56

32. Sung YY, Yoon T, Jang S, Kim HK (2016) Forsythia suspensa suppresses house dust mite extract-induced atopic dermatitis in NC/Nga Mice. PLoS One 11(12):e0167687

33. Ueda H, Yamazaki M (2001) Anti-inflammatory and anti-allergic actions by oral administration of a perilla leaf extract in mice. Biosci Biotechnol Biochem 65(7):1673-1675

34. Wechsler JB, Hsu CL, Bryce PJ (2014) IgE-mediated mast cell responses are inhibited by thymol-mediated, activationinduced cell death in skin inflammation. J Allergy Clin Immunol 133(6):1735-1743

35. Williams HC (2000) Epidemiology of atopic dermatitis. Clin Exp Dermatol 25(7):522-529

36. Yamaguchi T, Maekawa T, Nishikawa Y, Nojima H, Kaneko M, Kawakita T, Miyamoto T, Kuraishi Y (2001) Characterization of itch-associated responses of NC mice with mite-induced chronic dermatitis. J Dermatol Sci 25(1):20-28

37. Yang JH, Yoo JM, Cho WK, Ma JY (2016) Ethanol extract of Sanguisorbae radix inhibits mast cell degranulation and suppresses 2,4-dinitrochlorobenzene-induced atopic dermatitis-like skin lesions. Mediators Inflamm 2016:2947390

38. Yu H, Li H, Li Y, Li M, Chen G (2017) Effect of isoliquiritigenin for the treatment of atopic dermatitis-like skin lesions in mice. Arch Dermatol Res 309(10):805-813

39. Zeppa L, Bellini V, Lisi P (2011) Atopic dermatitis in adults. Dermatitis 22(1):40-46 